\title{
PROVIDENCE, CHANCE, DIVINE CAUSATION, AND MOLINISM: A REPLY TO ŁUKASIEWICZ
}

Dariusz Łukasiewicz's "Divine Providence and Chance in the World" provides abundant food for thought for anyone concerned with how God might act in a world where chance events seem to take place. As the paper is so rich-and, I must confess, at times perplexing, in part perhaps because complex matters are handled with extreme dispatch - my commentary will need to be limited and selective. After explaining why, according to Łukasiewicz, the strong traditional understanding of providence is no longer tenable, especially for one who adopts the current scientific picture of the world, I will argue that he has not made his case. I will then examine two directions a Christian might go so as to accommodate most of the attractive elements of Łukasiewicz's revisionary account without succumbing to the philosophical and theological defects his position exhibits.

Łukasiewicz tells us in his first paragraph that his goal is to support what he calls "the compatibility thesis," the claim that both "the existence of chance events is compatible with God's existence" and "chance might be part of divine providence" are true (p. 5). Initially, the compatibility thesis (henceforth CT) might not appear all that useful or provocative; after all, given the ambiguity of "chance," just about any advocate of divine providence will probably agree that there are some readings of CT under which it is true. Łukasiewicz, of course, is well aware of the various meanings that might be given to the word "chance," and in fact offers us six different readings of the term on page 6 . To be honest, what he offers us are not so much clear and complete descriptions of different types of chance but rather the starting points of such descriptions.

Thomas P. Flint, PhD, Professor of Philosophy at the University of Notre Dame; address for correspondence: Department of Philosophy, 417 Malloy Hall, University of Notre Dame, Notre Dame, IN 46556, USA; email: flint.1@nd.edu; https://orcid.org/0000-0002-7401-5948. 
An ontological chance, for example, is said to be one for which there is no detectable cause. How, one might wonder, is "detectable" being understood? Detectable for whom? For one of us, mere mortals? For God? And why should the detectability of a cause matter? If there are indeed causes for an event, causes that we (whoever "we" designates) cannot detect, then would it not make more sense to say that the event in question looks to be chance, but actually is not? Here is another example. A non-intentional chance, we are told, is an event which "is not intended or willed" by any personal agent. Here too, questions abound. What does "willed" encompass? If an agent knowingly permits something to take place, something that the agent would prefer not take place, is that event willed or not? ${ }^{1}$ Another concern with non-intentional chance: imagine a fully deterministic world in which there are no personal agents, and hence no intendings or willings. Does it not follow that, in such a world, everything takes place by chance, in this sense of the term? But is that not stretching the word "chance" beyond recognition? And so on for each of the six concepts of chance Lukasiewicz employs-each has a degree of mushiness to it. This would lead to problems with evaluating CT even if Łukasiewicz told us explicitly which of the six concepts he has in mind when stating and defending CT. But, alas, he does not. So we are a bit at sea in the paper almost from the start.

This sense of being adrift is troublesome, but also both understandable and to an extent pardonable in a paper of this sort, where so much territory needs to be covered so quickly. Perhaps the best way for us to move ahead is to assume (as seems reasonable, given his later discussion) that Łukasiewicz means for CT to cover chance events regardless of which of the six concepts he introduces is being assumed. CT could then be taken (still somewhat loosely) to mean that chance events of all six types are compatible with the existence and providential nature of God. ${ }^{2}$

\footnotetext{
${ }^{1}$ Molina offers a plausible account of permission which implies that something can be permitted but not willed: "someone is said to permit that which he (i) foresees as going to be unless he prevents it, (ii) is able to prevent, and yet (iii) does not will to prevent." See Disputation 49, Section 14 in Luis de Molina, On Divine Foreknowledge: Part IV of the Concordia, trans. and ed. Alfred J. Freddoso (Ithaca, NY: Cornell University Press, 1988), 122. For an excellent compact discussion of the various senses of "will" according to Aquinas, see FredDoso, ed., On Divine Foreknowledge, 244n13.

${ }^{2}$ Łukasiewicz says (see 15n18; see also similar assertions on pages that follow) that his view does not countenance non-intentional chance events because "if our argument is correct, chance events are intended and willed by God." But this comment strikes me as confused. On his view, what God wills or intends is that there be chance events. For any specific chance event that occurs, though, his position (if I understand it correctly) is that such an event is neither intended nor willed by God. So, he does indeed seem committed to chance events of all of his six types.
} 
Łukasiewicz implies that $\mathrm{CT}$ is worthy of our attention because contemporary science "tells us that chance events do happen in the world" (p. 5). In the course of the paper, Łukasiewicz points to various areas of science in support of his view. It is interesting to note that, typically at least, different notions of chance seem at times to be in play in these various fields. Darwinian evolutionary theory, we are told, "is founded on random genetic mutations within an organism's genetic code, i.e., the theory presumes chance events" (p. 10). Now, in which of our six senses does Darwinian evolutionary theory presuppose chance? Not, one would think, in the sense that it presupposes ontological chance - at least, not unless one wants to exclude Darwin and his Victorian supporters as advocates of evolution. For theirs, of course, was still a world thought to be thoroughly deterministic; that the seemingly random mutations required by the theory of evolution had causes, causes which science at least in theory might be able eventually to detect, would have been widely assumed. To discover the kind of randomness that one might credibly claim is central to the theory, one would need to look elsewhere-to events that are not brought about by any person's intention or will, say, or perhaps ones that lack meaning or purpose. ${ }^{3}$ With quantum mechanics $(\mathrm{QM})$, on the other hand, what seems central is that a particle's collapse to a specific spatial location is not determined by the physical state of the system prior to that collapse. Here, then, the notion of chance seems to be at least a species of ontological chance: there is no physical cause for the particle's location being here rather than there.

In whatever senses of "chance" modern science presupposes chance, then, why think of it as relevant to our view of providence? According to Łukasiewicz, the traditional notion of divine providence (henceforth TNDP) includes the following three theses:

(a) There is a perfect divine plan and every creature is subject to sovereign and unchangeable divine will.

(b) God knows from eternity all, even the smallest, events which come to happen: "all are open and laid bare to his eyes," including those things which are yet to come into existence through the free action of creatures.

(c) The divine care and love are direct and detailed: "for you love all things that exist, and detest none of the things that you have made; for you would not have made anything if you had hated it. How would anything have endured, if you had not willed it?" (p. 10)

\footnotetext{
${ }^{3}$ I say "might credibly claim" because it is in fact not clear that an advocate of evolutionary theory needs to make either of the claims mentioned here. What is crucial, one would think, is the idea that the theory does not require that, say, a particular case of mutation be intended or willed by anyone, or be an element in something that has meaning and purpose. We will return to this matter later in the paper.
} 
In essence, then, TNDP sees God's omnipotence, omniscience, and omnibenevolence as comprehensively manifested in the world he has created. All that happens is in one way or another part of his overall plan; nothing is too small or insignificant to be known, and knowingly intended or permitted, by him; nothing takes him by surprise; and all works together to achieve the good end for his world that God has ordained. As Łukasiewicz rightly notes, this is a picture of providence that has been dominant in the Christian tradition for many centuries; until very recent times, few serious Christian intellectuals would have seen it as negotiable.

How exactly is TNDP at odds with the modern scientific outlook on the world? Or, to put the question more accurately: Why have many theists who adopt that outlook thought that doing so mandates that TNDP be abandoned, or at least revised? It is hard to see precisely what Lukasiewicz thinks the answer to that second question is, but central to it seems to be the idea that the types of chance presupposed by science render belief in the God described by TNDP superfluous if not groundless. Science, they say, reveals "the emergence of complex, functionally well-organized structures from many unpredictable and purposeless events ... which are not designed by any mind" (p. 15). The absence of the need for a supernatural providential source means, they conclude, that religious belief sits uneasily with a modern scientific worldview.

If this familiar line of thought is the reason that science is proposed as being at odds with TNDP, it is really not a particularly impressive case. Evolution, for example, offers a story which allows us to see how seemingly designed organisms could come to be in the absence of a designer. This might well be telling if one's belief in God, and in TNDP, were based solely on certain versions of the argument from design. But if that is not the case, then it is not at all clear that TNDP has been discredited. The fact that a series of events conceivably could be unguided and purposeless and yet yield remarkably complex and well-structured organisms offers us scant reason to think that this development was unguided and purposeless - that no designing deity of the kind incorporated in TNDP was acting, in one of the ways to be discussed, to achieve that remarkable end. Similarly, as we shall see, the fact that QM seems to require the absence of a physical cause for certain events gives us no grounds for concluding that such events have no cause whatsoever.

Despite the weakness of this type of attempt to use science to undermine TNDP, Łukasiewicz feels that it nevertheless needs to be, if not rejected, at least radically re-interpreted; as he puts it, "the traditional idea of God's perfection and providence is untenable" (p. 26). Why does he think abandoning the tradition here is needed? And what does he propose we put in its place? 
Łukasiewicz offers three reasons for thinking that TNDP needs to be re-conceived. First, "the idea of God whose goodness is manifested in the total control over every being is unconvincing and incompatible with our intuition of goodness; loving parents allow their children to make independent and authentic choices, especially if the choices concern important issues" (p. 26). The argument here, note, has nothing to do with a contemporary scientific outlook. If the God of TNDP is indeed so controlling as to not allow his creatures any degree of genuine agency and autonomy, then one need not turn to QM or to Darwinian evolution to make the case that TNDP, as traditionally understood, is unappealing.

But is the God of TNDP the control freak Łukasiewicz makes him out to be? That depends upon whether divine control needs to be exercised in a way that robs us of significant freedom. If God's sovereignty could be exercised through our free actions rather than by squelching them, then the alleged need to choose between God's control and ours would be discredited. And as we will soon see, this is precisely what the Molinist view of providence professes to do.

So Łukasiewicz's first reason for abandoning the tradition seems at best premature. His second reason concerns whether God's sovereignty needs to be as specific as the tradition has suggested in order for him to achieve his ends. "The belief that lack of God's total control over every detail and every single particle in the world may limit His sovereignty and freedom is an expression of anthropomorphism of God's omnipotence, and it is simply mistaken" (p. 26). Even without exercising specific sovereignty over everything that occurs, God's omnipotence means that he can achieve whatever he will:

... the idea of God's perfection entails that nothing can limit God's omnipotence and will. Neither lack of control over chance events, nor the eternal and immutable principles of morality, logic and mathematics, nor any metaphysical doctrine can do that because for God nothing is impossible. (p. 27)

Genuine omnipotence, says Łukasiewicz, means that God need not fret over the details, nor engage in any kind of exhaustive planning:

... God created the world without any meticulous plan, because he did not need such a plan. The omnipotent creative divine will needs no plans and is not limited by any possibilities (possible worlds), nor any necessities. ... God cannot be viewed as the true Lord of absolutely everything in the universe if His "strong" providence is hostage to such irrelevant, minute details. (p. 29)

What are we to make of this reason for abandoning the more traditional stance? First, the claim that there are absolutely no limits on what God can do-that 
nothing for him is impossible - strikes me as both philosophically bankrupt and theologically destructive. Let me consider these two points separately.

All of us come to philosophy with strong modal intuitions - intuitions that some things really could have been other than they are (i.e., that there are possibilities that are not actual) and that some things could not have been other than they are (i.e., that there are actualities that are necessary). London is more populous than Liverpool, but things did not have to turn out that way; it is possible that Liverpool have expanded exponentially while London shrank into a minor hamlet. Those of us not frightened by modern philosophical terminology might even express this ordinary, common-sense intuition by saying that there are possible worlds in which Liverpool is more populous than London. So, some things really could have been other than they are. But some could not. It is simply not possible that 17 be an even number, or that it be both an even number and an odd number. It is not possible that London be both larger and smaller in population than Liverpool, or that God be nothing more than an iambic pigeon created by a four-sided sphere. All of these claims are, our modal intuitions assure us, impossible - true, as contemporary philosophers say, in no possible world. And the negation of what is impossible is quite simply necessary-true in every possible world. This is where any sensible philosophy needs to start: some things are possible, some impossible, and some necessary. ${ }^{4}$ And such modal realities mean that some things quite simply cannot be done by anyone, no matter how perfect or powerful an agent might be. No one, not even God, can bring it about that 17 is an even number. ${ }^{5}$

So, the claim that nothing, for God, is impossible strikes me as solidly at odds with our ordinary pre-philosophical convictions. But it also would mean an end to any genuine theological reflection and discussion. Suppose Professor X presents us with a new theory of the Incarnation. His student Clare points out that the theory entails something that seems impossible - say, that Jesus was a human being who lacked a feature (call it $Z$ ) essential to every human being. And suppose she takes

\footnotetext{
${ }^{4}$ Needless to say, we may be less than sure, in many cases, as to what goes into what category. Many theists believe that it is necessary that God exist; many atheists think it is impossible that God exist. So, there is no consensus on the modal status of "God exists"; sensible people disagree. What they will not disagree on, if they really are sensible, is that some things are necessary, some possible, and some impossible.

${ }^{5}$ It is possible that Łukasiewicz would take issue with the propriety of our wondering about whether God could bring such a thing about. While he does insist (footnote 42) that for God's will "there are literally no limits," he also says (p. 27) that God's will "is what it is, and further deliberation on our part whether the divine will might be different ... makes no sense." The first of these claims suggests that God surely could have willed otherwise with respect to 17's being even; the second suggests that we should not speculate on whether he could have willed otherwise. I have to confess I do not see how to put such statements together so as to form a coherent position.
} 
this, reasonably enough, as an objection to his theory. Professor X, though, does not. "Poor Clare," he says, "you need to free yourself of the old-fashioned idea that there are things God can't do. Yes, on my theory, Jesus was human. Yes, on my theory, Jesus lacks Z. And yes, Z is essential to every human. But, don't you see, nothing can limit God's omnipotence and will. If he chooses to bring it about that the human Jesus lacks a trait all humans by nature must have, he can do it! He's not subject to your new-fangled talk of possible worlds, of necessities and possibilities; omnipotence means freedom from any and all such limitations." And then he concludes his response with: "Next question?" Would it surprise us if there were no volunteers?

The claim that nothing limits God is indeed the ultimate conversation-stopper for theology. Once that card has been played, the game is really over. No objection, however, seemingly persuasive, can withstand the "But God can do anything!" riposte. True, it does make available an irenic solution to all perceived disagreements. Professor X again: "Yes, Clare, on my theory, Jesus lacks trait Z. You think he has Z since he's human. How about this: He has Z, and he lacks Z. If God can do anything, surely he can bring that about. So we're both right!" Irenic indeed. But also deadly to serious theological discourse.

Now, one might well think that there is a deeper and more tenable element to Łukasiewicz's second reason for rejecting the traditional understanding of TNDP. For part of his objection here is that God cannot truly be seen as all-powerful if he needs to make careful and minute plans - if he is "hostage" to irrelevant, minute details. God should be able, he implies, to pay attention to the big picture and ignore the little stuff. Indeed, he can allow lots to happen by chance, not at all controlled by him, and still achieve his overall goals for the world.

If we leave aside the "God can do anything" charade, though, it is hard to see exactly how this is supposed to work. It is not at all easy to separate the big, important stuff from the middle-sized and the tiny stuff. Where exactly (or even approximately) is God's supervision supposed to end? Besides, typically, the success of a large-scale project depends upon innumerable small-scale elements. We humans, with our limited time and resources, often have to ignore the details, and hope that things work out. As the head contractor for a new building, I cannot inspect every centimeter of wiring that is being installed; indeed, not even the electricians who work for me can. We execute larger-scale plans, and hope that the details align. But if they do not, those plans, like our buildings, can go up in flames. God's projects, like ours but (of course) on a much large scale, also often depend upon the details working out correctly. And with the way in which events in his world are intricately interconnected, the extra grain of sand in the balance here can ultimately result in 
the untimely death of a major actor in, say, God's salvific plan. If the flapping of a butterfly's wings can change the course of a tornado, it can also throw a monkeywrench into the path that leads to Incarnation and redemption. If salvation history is the grand and magnificent production that we Christians believe it to be, it seems hard to believe that God could orchestrate all of this without paying attention to the details. He is not "hostage" to them; he simply realizes that, as with his human children, the small and seemingly insignificant often have a crucial role to play. With the macroscopic depending as it does on the microscopic, success with the former requires attending to the latter. Besides, it is not as if he is not up to the task. We may have to devote our limited power and energy to the larger-scale elements of our projects and hope the butterflies do not get in the way. God, as Lukasiewicz would no doubt agree, is not thus limited.

Let us now turn to Łukasiewicz's third reason for questioning the traditional understanding of providence. TNDP needs to be reconceptualized, he says, because "lack of chance events in the world would diminish the degree of diversity in the world. God's generosity consists, among others, in the fact that God created the world, and it is a world with a multitude of types and tokens of various creatures, where diverse oppositions obtain" (pp. 27). Having some events that are "without any cause, unpredictable or purposeless, as quantum physics claims" (p. 28) adds to this diversity. The picture we get, then, is of a God who welcomes the purposeless and the uncaused, and can achieve his ends in creation by graciously allowing such events to occur.

To the extent that this third reason for revising TNDP presupposes that largescale divine guidance can and should be combined with small-scale divine indifference, we have already seen grounds for concern. Still, there is surely more to this third reason that cannot be so easily dismissed. The value of diversity and the generosity of God's willing to create secondary agents with genuine agential power is surely hard for a Christian to deny. The fact of the matter, though, is that few if any advocates of TNDP as traditionally conceived have thought that these values require the weakening of that doctrine in the ways that Łukasiewicz proposes. The virtues that he highlights can be present even if God is not the often hands-off spectator that Łukasiewicz makes him out to be. ${ }^{6}$

\footnotetext{
${ }^{6}$ It is worth noting that Łukasiewicz also tries to defend the idea of God's complete omniscience by making him a spectator. If God is outside of time, then he can see what goes on at all times even if lacks control over some of the events he sees. For reasons to be concerned about the adequacy of this observational model of divine knowledge, see my Divine Providence: The Molinist Account (Ithaca, NY: Cornell University Press, 1998), 82-84, and Alfred FredDoso, "Introduction," in On Divine Foreknowledge, by Luis de MoLINA, 30-36.
} 
In the remainder of this paper, I would like briefly to discuss two ways TNDP can be defended without diluting the doctrine of providence and without ignoring the virtues of ontological diversity and theistic generosity that Łukasiewicz rightly lauds. The first, discussed (among others) by Alvin Plantinga, allows for the existence of the physically undetermined events QM seems to require, but suggests that we can see God as the ultimate causal determiner of most such events. On this view, then, genuine ontological chance does not exist, but God's determining action typically takes place at a level beyond our observational capacities. The second way of defending diversity is that made possible via the Molinist account of providence. On this view, we can, if we wish, allow that the world includes events (at the QM level or, conceivably, elsewhere) that neither God nor any other person causes - which do indeed fall under Łukasiewicz's category of ontological chance. On this Molinist perspective, though, none of these events need be seen as exempt from God's genuine providential control.

Consider first Plantinga's suggestion of what he calls divine collapse-causation (DCC). ${ }^{7}$ Plantinga notes that not all QM theorists accept the assumption of the Copenhagen interpretation that all collapses are precipitated by measurements. According to the Ghirardi-Rimini-Weber (GRW) approach, collapses occur spontaneously, frequently, and regularly (ten million times a second), and no physical properties of the system determine the outcome of any collapse. Within the realm of the physical, then, these are indeed ontologically chance events. But if we go beyond the physical, we open the door to the possibility of divine causation.

... on these approaches there is no cause for a given collapse to go to the particular value (the particular position, for example) or eigenstate to which in fact it goes. That is, there is no physical cause; there is nothing in the previous physical state of the world that causes a given collapse to go to the particular eigenstate to which it does go. But of course this state of affairs might very well have a nonphysical cause. It is wholly in accord with these theories that, for any collapse and the resulting eigenstate, if is God who causes that state to result. ${ }^{8}$

\footnotetext{
${ }^{7}$ See Alvin Plantinga, Where the Conflict Really Lies: Science, Religion, and Naturalism (New York: Oxford University Press, 2011), 114-21. It is perhaps worth emphasizing that Plantinga is by no means wedded to the idea of DCC. What it offers us, he says, is one way of seeing how God could be actively involved in the world in a way that seems fully in accord with everything contemporary physics has shown. Our belief that God is involved in the world, though, should itself be neither derived from nor dependent upon this or any other specific scientific theory. On this last point, see p. 120.

${ }^{8}$ Plantinga, Where the Conflict Really Lies, 116.
} 
Plantinga goes on to note that, given the kind of dependence (which we have already discussed) of the macroscopic on the microscopic, DCC would allow God to exert considerable providential guidance over his world, including producing the kinds of miraculous events (e.g., changing water into wine, or bringing a dead man back to life) so central to Christian belief. Thus, on this approach, we get both seemingly-chance events along with the strong notion of divine control that has always been central to TNDP.

Łukasiewicz is aware of this means of defending TNDP (he refers to it as a type of epistemic deism) and offers three objections. But none of these objections is at all effective against Plantinga's suggestion. First, says Łukasiewicz, Plantinga is really offering us a version of "theological determinism, which is incompatible with human freedom and independence of the created universe from its Creator" (p. 19). But Plantinga has anticipated such an objection and offers a remedy: perhaps we free humans, being (at least partially) immaterial substances, are able to cause the collapse-events that are relevant to our actions. "God sets the stage for such free action by causing a world of regularity and predictability; but he causes only some of the collapse-outcomes, leaving it to free persons to cause the rest." Second, according to Łukasiewicz, Plantinga's approach "entails limitations of divine omnipotence because God can act in the world only at the quantum level, in a way permitted by quantum indeterminism of probabilistic laws, and God always has to act at the quantum level" (p. 19). But this is to misinterpret Plantinga's position. As he noted in 2014,

... being omnipotent, God can act at any level he wants. My suggestion is that he chooses to create in a certain way: he creates systems of particles (along with the macroscopic objects they compose) in such a way that they undergo collapses of their wave functions at a regular rate; and then God causes these collapses to go to the values to which they do indeed go. Nothing compels him to do things this way; rather, this is just the way he has decided to do things. No doubt he could have decided on many different arrangements; this is the one he chose (on the suggestion). ${ }^{10}$

Finally, Łukasiewicz complains that if God abides by the laws of nature he has established, he will not be able to "fulfill his promises, for example, the biblical promise of the new Earth and new Heaven" (p. 19), since such a transformation of

\footnotetext{
${ }^{9}$ Ibid., 120.

${ }^{10}$ Alvin Plantinga, "Response," Philosophia Reformata 79, no. 1 (2014): 91. The quoted section comes from the portion of his paper where he is responding to Ignatio SILVA's "Great Minds Think (Almost) Alike: Thomas Aquinas and Alvin Plantinga on Divine Action in Nature" (pp. 8-20) in the same issue of Philosophia Reformata.
} 
the current world will not, according to current cosmology, be physically possible. Again, Plantinga's response seems obvious: to think of God as being required to abide by the physical laws he has established for the current age once we have moved into an eschatological age is to conflate rules valid here and now for ones that are universally constraining.

So, nothing that Łukasiewicz says gives us any reason whatsoever to reject Plantinga's suggestion. And since that suggestion is fully in line with the strong, traditional understanding of divine providence, it seems an attractive means of showing how the acceptance of genuine physical indeterminism need not lead either to an embrace of events that are ultimately uncaused or to an attenuated understanding of TNDP.

Suppose, though, that one feels that Plantinga's suggestion does not go far enough to address the aforementioned issues of generosity and variety. Suppose one feels that God's universe truly would be a more worthy product of his gracious creativity if it included events that were utterly uncaused - that were genuine instances of what Łukasiewicz calls ontological chance. It is important to note that this need not lead one toward the depreciated version of TNDP that Łukasiewicz proposes, one where creaturely variety and independence are bought at the price of divine control. Molinism offers what is to my mind a clearly preferable option. Let me explain by first, very briefly, describing the Molinist approach to providence.

Molinists assume that TNDP, as traditionally conceived, is true. God is truly sovereign of all that occurs. Nothing, not even the smallest detail, is outside of his overall plan for the world. And because all that occurs stems from God's creative decisions, he knows all that lies in our future. Foreknowledge, for the Molinist (as for most traditional Christians), is not explained by God's passively looking down on the temporal realm from his secluded timeless aerie; rather, it follows from his exercise of divine sovereignty.

The other cornerstone of Molinism is the libertarian account of freedom-the contention that, for an action to be free, its ultimate causal determinant must be found in the agent, not in other persons or prior events. This libertarian picture of freedom stands opposed both to hard determinism (the claim that none of our actions is free because all of our actions are ultimately caused by events long before our births, events over which we exercise no control) and to compatibilism (according to which, since some of our actions are both free and causally determined by external events that occurred prior to and independent of any exercise of our will, it follows that freedom and causal determinism must be compatible). While hardly a universal view among theists, libertarianism has been widely accepted among 
traditional Christian philosophers and theologians, and is (many would argue) the picture of freedom that most of us presuppose prior to philosophical theorizing.

Those who accept traditional notions of God's sovereignty, foreknowledge, and libertarian freedom face an obvious challenge. The situations in which a free agent (call her $F$ ) is placed do not determine her to act in any specific way. If $F$ is placed in circumstances $C$, circumstances that leave her free with regard to doing $A$ or not doing $A$, then either outcome is compatible with her being in $C$. So God's decision, as sovereign creator, to place $F$ in $C$ could result in $F$ 's doing $A$ or in $F$ 's not doing $A$. How, then, can God be enacting a specific, fine-grained providential plan if either response could result from his placing $F$ in $C$ ? And how, having decided to put $F$ in $C$, can he have active foreknowledge (as opposed to passive, observational knowledge) of what $F$ will do?

According to Molina, the only adequate response we can offer here is to insist that, before performing any creative act, God knew how $F$ would freely respond if she were to be placed in $C{ }^{11}$ Suppose that, when deciding what creative actions he will perform, God knows the following conditional: If I were to create $F$ and put her in $C$, she would freely do $A$. Should God then decide to create $F$ and place her in circumstances $C$, an immediate consequence of that decision would be the knowledge that $F$ will do $A$ in $C$-and do it freely, not because anything in the circumstances causally necessitates this action. Knowledge of such a conditional (an instance of what philosophers engaged in this discussion have come to call counterfactuals of creaturely freedom) would thus seem to provide us the means to bring together genuine divine sovereignty and comprehensive creative foreknowledge with real creaturely freedom. And if God's knowledge is not limited to this one counterfactual-if, rather, he knows how any free creature he might create would act in any situation in which it might be created and left free- - then the genuine libertarian freedom of all creatures, not just of $F$, would be reconciled with divine sovereignty and foreknowledge. God's providential control over his world would be exercised, in large part, not by his causally determining everything that his creatures do, but by his putting them in situations in which he sees, via his knowledge (typically called middle knowledge), that they will freely (if often unknowingly) cooperate with him in achieving his ends.

${ }^{11}$ The "before" here at least suggests that God is in time, and that his deliberations temporally precede his actions. Molina, though, along with many of his followers, sees God as outside of time, and would think of the temporal language here as a natural (since, for us, deliberation does in most cases temporally precede action) but potentially confusing means of pointing to what is more a dependence than a temporal relation. See my Divine Providence, pp. 37 and 174-76. 
Molinism has always been, and remains, a very controversial theory; it has always had, and continues to have, able defenders and able detractors. Anyone unfamiliar with the controversy would be well-advised to avoid precipitate judgments until looking at the arguments on both sides. ${ }^{12}$ My point in raising the theory here is to point out that, if one ends up agreeing (as I and many others, including Plantinga, have) that Molinism offers a singularly attractive means of reconciling our freedom with God's providence, then it offers one an analogously appealing way of allowing genuine ontological chance into the world without weakening TNDP in the ways Łukasiewicz proposes.

Consider those counterfactuals of creaturely freedom described above. What is crucial to their being part of God's middle knowledge - his knowledge of contingent truths which are not subject to his will-is that they describe how a causally undetermined event (such as $F$ 's doing $A$ in $C$ ) would in fact turn out. Now suppose, as Łukasiewicz thinks we should, that there are causally undetermined events that are not free actions - i.e., not the acts of personal substances with intellect and will. Take, for example, a specific eigenstate $E$ that results from the collapse of a certain system of particles $S$ placed in conditions $C$. Consider then the counterfactual conditional If $S$ were in $C$, the collapse-outcome would be $E$. What we have here, note, is a counterfactual exactly parallel to the counterfactuals of creaturely freedom. Why not say that such conditionals would also be part of God's middle knowledge? Indeed, if God does possess knowledge of what undetermined human behavior would occur in various circumstances, why would he not possess knowledge of what undetermined microphysical behavior would occur in various circumstances? But if he does, then just as he can use middle knowledge to guide and control events at the level of free humans, so he can employ his middle knowledge to guide and control events at the level of microphysical particles. ${ }^{13}$ And by doing so-by deciding which such particles to create and what situations to put them in so as to bring about the macrophysical events that best serve his providential plans (and, of course, avoid the macrophysical events that would not serve those needs) - he can exercise the kind of active divine control over

${ }^{12}$ A number of excellent essays on all sides of the discussion can be found in Ken PerszYK, ed., Molinism: The Contemporary Debate (Oxford: Oxford University Press, 2011). This volume also boasts a comprehensive bibliography which (though now slightly out of date) lists all of the major contributions to this debate.

${ }^{13}$ Molina (in Disputation 47, Section 13 of the Concordia, pp. 96-97 of the Freddoso volume) makes it clear that he is open to the possibility of events other than free actions that are not causally determined, even though he sees no reason to believe that in fact such events occur. So, it seems clear that he would also be open to the type of approach discussed in this paragraph. For further discussion of this matter, see FREDDOSO, "Introduction," 28-29. 
his world that the traditional understanding of TNDP has long championed. The genuine ontological chance events that Łukasiewicz believes (wrongly, perhaps) modern science requires and that he thinks (rightly, perhaps) enrich God's creation can be accommodated, if one so wishes, without weakening the strong traditional understanding of providence. ${ }^{14}$

My conclusion, then, is that Łukasiewicz offers us insufficient reason to tinker with the model of providence Christians have long embraced. If one agrees with Łukasiewicz that true ontological chance should have a place in God's world, then Molinism provides one a ready means of allowing for such events without seeing them as exceptions to God's providential activity. On the other hand, if one thinks that having some events in the world that are not consequences of physically determining causes is sufficient for the kind of diversity Łukasiewicz admires, then Plantinga's notion of divine collapse-causation seems to offer us what we need while holding on to an unadulterated understanding of TNDP. Abandoning a major part of traditional philosophical and theological reflection should be entertained, it seems to me, only if we are offered an exceptionally strong case that such a transition needs to be made. As I see it, Łukasiewicz fails to make such a case.

\section{BIBLIOGRAPHY}

Flint, Thomas P. Divine Providence: The Molinist Account. Ithaca, NY: Cornell University Press, 1998. Freddoso, Alfred J. "Introduction." In On Divine Foreknowledge: Part IV of the Concordia, by Luis de Molina, 1-81.

Molina, Luis de. On Divine Foreknowledge: Part IV of the Concordia. Translated and edited by Alfred J. Freddoso. Ithaca, NY: Cornell University Press, 1988.

PerszYK, Ken, ed. Molinism: The Contemporary Debate. Oxford: Oxford University Press, 2011. Plantinga, Alvin. "Response." Philosophia Reformata 79, no. 1 (2014): 91.

Plantinga, Alvin. Where the Conflict Really Lies: Science, Religion, and Naturalism. New York: Oxford University Press, 2011.

SILVA, Ignatio. "Great Minds Think (Almost) Alike: Thomas Aquinas and Alvin Plantinga on Divine

Action in Nature." Philosophia Reformata 79, no. 1 (2014): 8-20.

14 The "if one so wished" should not be overlooked. Nothing in the Molinist stance requires that there be ontological chance events of the kind discussed here. Indeed, a Molinist could disagree with Molina regarding even the possibility of such events. The point of this paragraph is merely that, if there are such events, they pose no problem for the strong traditional notion of providence so long as a Molinist approach is employed. 


\section{PROVIDENCE, CHANCE, DIVINE CAUSATION, AND MOLINISM: A REPLY TO ŁUKASIEWICZ}

\section{Su m m ary}

Dariusz Łukasiewicz's "Divine Providence and Chance in the World" attempts to show that the strong traditional understanding of providence is no longer tenable, especially for one who adopts the current scientific picture of the world. In its place, Łukasiewicz suggests, we need to adopt a view of providence which allows for genuine chance events not controlled by God. I argue that he has not made his case on the need for the traditional view to be abandoned. I then examine two directions a Christian might go so as to accommodate most of the attractive elements of Łukasiewicz's revisionary account without succumbing to the philosophical and theological defects his position exhibits.

Keywords: providence; chance; Plantinga; quantum mechanics; Molinism.

\section{OPATRZNOŚĆ, PRZYPADEK, BOSKA PRZYCZYNOWOŚĆ I MOLINIZM: ODPOWIEDŹ ŁUKASIEWICZOWI}

\section{Streszczenie}

Esej Dariusza Łukasiewicz Opatrzność Boga a przypadek w świecie ma dowodzić, że silne tradycyjne rozumienie opatrzności nie da się utrzymać, zwłaszcza w świetle współczesnego naukowego obrazu świata. W jego miejsce Łukasiewicz proponuje koncepcję Opatrzności, która dopuszcza autentycznie przypadkowe zdarzenia, których Bóg nie kontroluje. Argumentuję, że argument Łukasiewicza jest nieudany. Następnie rozważam dwa sposoby, w jakie chrześcijanin mógłby uwzględnić większość atrakcyjnych składników rewizyjnej koncepcji Łukasiewicza, unikając filozoficznych i teologicznych wad jego stanowiska.

Słowa kluczowe: Opatrzność; przypadek; Plantinga; mechanika kwantowa; molinizm. 